HID 45 (2018)

\title{
MÚSICA Y PODER MUNICIPAL EN JEREZ DE LA FRONTERA. SIGLOS XVI-XVII ${ }^{1}$
}

\author{
MUSIC AND MUNICIPAL POWER IN JEREZ DE LA FRONTERA. \\ $16^{\mathrm{TH}}-17^{\mathrm{TH}}$ CENTURIES
}

\author{
Juan Antonio Moreno Arana \\ Universidad de Huelva \\ jarenoara@gmail.com ORCID: https://orcid.org/0000-0002-9861-7740
}

RESUMEN: Se analiza los usos de la música por parte del cabildo municipal de Jerez de la Frontera durante la Edad Moderna, así como la gestión de estos servicios musicales. Se exponen los distintos tipos de profesionales e intérpretes relacionados con lo sonoro que se vinculan laboralmente con el poder civil de esta ciudad. Finalmente, se hace un breve estudio sociológico sobre estos músicos.

Palabras ClaVes: Jerez de la Frontera; Poder municipal; musicología histórica; ministriles; trompetas; tambores.

ABSTRACT: This study analyzes the uses of music by the municipality of Jerez de la Frontera during the Modern Age. The different types of professionals and interpreters related to the music that work for this city are studied. Finally, a brief sociological study about these musicians is made.

KeYwORDS: Jerez de la Frontera; municipal power; historic musicology; minstrels; trumpets; drums.

\section{INTRODUCCIÓN}

La música como representación del poder se consolida y toma un impulso definitivo con la Edad Moderna. En efecto, el avance de la vida urbana y el afianzamiento de sus instituciones extienden por la geografía hispana y europea

Recibido: 3-9-2017; Aceptado: 21-5-2018; Versión Definitiva: 4-6-2018.

1. Abreviaturas utilizadas: AHMJF = Archivo Histórico Municipal de Jerez de la Frontera; AHDAJ = Archivo Histórico Diocesano Asidonia-Jerez, APNJF = Archivo de Protocolos Notariales de Jerez de la Frontera; sec. = sección.

Copyright: (C) Editorial Universidad de Sevilla. Este es un artículo de acceso abierto distribuido bajo los términos de la licencia de uso y distribución Creative Commons Reconocimiento-No-ComercialSinObraDerivada 4.0 (CC BY-NC-ND 4.0) 
un fenómeno con un largo recorrido histórico, pero que llegaba ahora, bajo el influjo de la emulación, a todo tipo de corporaciones. Y a la misma par que los modos de exhibir, afirmar o recrear en los contextos públicos, festivos, ceremoniales o bélicos un status preeminente o la adhesión a unos valores religiosos y políticos, los paisajes sonoros como expresión ideológica se harán cada vez más complejos $^{2}$.

Jerez de la Frontera, en los siglos modernos, y en especial durante el Quinientos, como nudo geoestratégico dentro de las redes de comunicación del Imperio Hispánico, adquiere un relevante estado económico y social. Obligado por estas circunstancias, su concejo municipal no pudo ser ajeno a ese ambiente de encendida competencia entre instituciones. Lo sonoro formará parte, así, de los procesos de construcción simbólica y de exhibición de la legitimidad de su poder político. $\mathrm{Y}$ aquí, dos hitos, dos espejos en los que tendría necesariamente de mirarse, se alzaban delante de los regidores jerezanos: a un lado, Sevilla, capital económica, administrativa y eclesiástica, ciudad de la que Jerez fue eterna émula. En el otro, en el corto trecho de unas calles, casi pared con pared, el cabildo eclesiástico de la iglesia mayor colegial, no menos combativo en la empresa de trazarse una entidad que aspiraba a mayores cotas de potestad y autoridad ${ }^{3}$.

\section{LA VISIÓN DE LOS REGIDORES JEREZANOS CON RESPECTO A LA MÚSICA COMO EMBLEMA DEL PODER}

La necesidad de la música como signo del poder se resumía en dos conceptos: "autoridad" y "ornato". El cabildo de la catedral de Sevilla, por ejemplo, justificó en 1553 el acompañarse de ministriles por ir honrradas y autorizadas en las procesiones a las que asistía ${ }^{4}$. Son similares manifestaciones, yéndonos al caso que nos ocupa, a las que realizó el veinticuatro jerezano Pedro Riquel en 1563. En una reunión capitular en la que se deliberaban los pormenores de la contratación de una compañía de ministriles, Riquel se mostró a favor de la contratación exponiendo:

que le paresçe que es cosa conbynyente para el servycio de dyos y su magestad, porque en las fiestas que se hazen del santísimo sacramento e de otras cosas en las yglesias proboca a gran deboción y en los rebatos y fiestas desta cibdad le paresçe que dan abturidad 5 .

2. Al respecto: Strong 1988, p. 33; Bonet Correa 1990; Ruiz Jiménez 2004, pp. 201-201; Astruells Moreno 2005; Carreras 2005, pp. 38-44; Carter 2005, pp. 53-66; Sanz Ayán 2009; Bejarano Pellicer 2013; Atkinson 2016.

3. Sobre la capilla musical de la Colegial de Jerez: Repetto Betes 1980; En relación a las políticas y prácticas musicales en la Sevilla del siglo de Oro: Bejarano Pellicer 2013. En el mismo sentido, habría que sopesar la influencia que pudo ejercer sobre la ciudad jerezana la vecina "Corte musical" de los Medina Sidonia. Sobre el mecenazgo musical de los duques de Medina Sidonia: Gómez Fernández 2017.

4. Ruiz Jiménez 2004, p. 203.

5. AHMJF, sec. I, Actas Capitulares, tomo 20 (años 1562-1564), f. 263v. 
En iguales términos se expresó el también veinticuatro Juan Fernández de Herrera en 1585 cuando los regidores debatían si solicitar o no la renovación de la licencia real que permitía utilizar dinero de la hacienda municipal para la contratación de músicos. Decía Fernández de Herrera: que es cosa conbiniente que la cibdad tenga ministriles para su hornato ${ }^{6}$.

Y a mayor despliegue de músicos, más "autorizados" quedaban la Ciudad y sus regidores, y mucho más en ese contexto de rivalidad entre instituciones ya aludido. Lo comprobamos cuando en 1550 se vote en cabildo la contrata de dos trompetas para que el número de estos instrumentistas municipales fuera el de cuatro. En dicha votación, el veinticuatro Jerónimo Dávila arremetía contra una provysyon antigua que impedía ampliar el número de trompetistas. Según Dávila, no poder destinar más dinero para la contratación de trompetas iba en perjuizio del ornato desta cibdad?

Pero la utilización de la música iba más allá de la propia función de solemnizar los distintos actos ceremoniales. La Edad Moderna mantuvo viva la práctica social medieval de la llamada "economía del regalo" o "del don”. Así, la cesión o préstamo de servicios musicales era un acto que reforzaba la imagen de preeminencia del donante sobre otras instituciones, además de ser una maniobra de carácter diplomático ${ }^{8}$. Es por esta razón que los capitulares jerezanos no pusieran objeción alguna a solicitudes como la que hacía el comendador mosén Diego de Valera en marzo de 1549 para que se diera licencia a los ministriles municipales para ir a su residencia en el Puerto de Santa María a amenizar cierta fiesta ${ }^{9}$. Algo parecido pudo ocurrir hacia 1570 con los ministriles que se desplazaron a Sanlúcar para actuar en una celebración religiosa patrocinada por el VII duque de Medina Sidonia o en 1597 cuando los chirimías jerezanos fueron contratados para participar en las fiestas del Corpus de la citada ciudad ${ }^{10}$.

Ya dijimos que Sevilla, cabeza y promotora de todas estas prácticas musicales, hubo de ser el faro que alumbraría los pasos de los capitulares jerezanos. Para poner punto final a este recorrido por las concepciones ideológicas que determinan el empleo político de la música por parte de la institución municipal jerezana hay dirigirse, precisamente, a la capital hispalense. A mediados del siglo XVII, en su cabildo municipal tenía lugar el recurrente debate sobre si continuar costeando o no el empleo de ministriles municipales. Como argumentos principales para seguir manteniéndolos se apeló, por un lado, a que la grandeza y autoridad conbiene tenerlos para muchas cosas que cada día se ofrecen. Lo otro era que: porque por supuesto que la çiudad de xerez y cordoba y otras muchas çiudades en castilla tienen ministriles, es cosa muy puesta en rrazon questa ciudad los tenga ${ }^{11}$.

\footnotetext{
6. AHMJF, sec. I, Actas Capitulares, tomo 30 (años 1585-1586), f. 354.

7. AHMJF, sec. I, Actas Capitulares, tomo 16 (años 1548-1550), f. 288.

8. Bejarano Pellicer 2013, p. 230.

9. AHMJF, sec. I, Actas Capitulares, tomo 16 (años 1548-1550), f. 132.

10. Gómez Fernández 2017, p. 249, nota 239; Daza Palacios 2009, p. 167

11. Bejarano Pellicer 2013, p. 282.
} 
Los capitulares sevillanos avalaban, así, el esfuerzo económico que el ayuntamiento de Jerez había hecho para tener y mantener instrumentistas musicales a su servicio de modo permanente, señalando con ello que ese empeño no había sido en balde. Emulado y émulo habían intercambiado los papeles.

\section{Los músicos Al SERVICIO del CABILdo MUNiCIPAL de JeREZ a lo LARGO DE LA EDAD MODERNA}

La documentación del cabildo jerezano es el más fiel retrato de ese empeño. Y, especialmente, la documentación de los siglos XVI y XVII es la que ofrece más referencias sobre este asunto; elocuente señal de la importancia que la música tuvo dentro de las labores de gestión municipal de aquellos siglos.

Ya que su misión era la de realzar los diversos actos públicos y demás funciones protocolarias que en gran medida tenían lugar en espacios al aire libre estos músicos tañían instrumentos caracterizados por una gran sonoridad.

\subsection{Atabales y tambores}

Ambos instrumentos de percusión estaban estrechamente vinculados con la esfera de lo militar, aunque igualmente aparezcan en contextos festivos. Por ello, los caballeros capitulares diputados en asuntos militares o el alférez mayor de la ciudad eran los encargados de su contratación ${ }^{12}$.

En principio, el empleo de estos tambores fue eventual, pues la necesidad de una presencia continua de estos instrumentistas sólo tenía lugar durante la época de verano y otoño, cuando eran más probables las amenazas hostiles en la costa gaditana. No obstante, también podían ser contratados para ocasiones festivas puntuales: en 1535 se libraron seis reales de plata a los que tañeron los atabales en las fiestas de la toma de Túnez ${ }^{13}$.

La consideración de trabajador eventual del ayuntamiento, al menos durante el siglo XVI, se manifiesta en que no aparezcan en la relaciones de sueldos de los trabajadores municipales $(1482,1594)^{14}$. En 1594 se expresaba que las cinco compañías de la milicia jerezana tuvieran cada una de ellas un tambor, dándose de salario un real cada día que sirvieran ${ }^{15}$. Para el siglo XVII, sí se puede afirmar la existencia de una nómina fija de tambores municipales. En una relación fechada

12. Por ejemplo: AHMJF, sec. I, Actas Capitulares, tomo 19 (años 1559-1560), f. 276; AHMJF, sec. I, Actas Capitulares, tomo 31 (años 1587-1588), f. 515.

13. AHMJF, sec. I, Actas Capitulares, tomo 14 (años 1535-1539), f. 87.

14. Martín Gutiérrez 1996, p. 186; AHMJF, sec. I, Actas Capitulares, tomo 34 (años 1593-1594), f. $436 \mathrm{v}$.

15. AHMJF, sec. I, Actas Capitulares, tomo 35 (años 1595-1596), ff.196v.-197. Es interesante reseñar el dato de que algunos de estos tambores fuesen gitanos y que, como el caso de Lorenzo Cortés, ejercieran asimismo el oficio de herrero, actividad muy vinculada con este grupo social que los capacitaría físicamente para el toque del tambor: AHMJF, sec. I, Actas Capitulares, tomo 48 (1629-1631), f. 314; tomo 50 (años 1634-1635), f. 601; tomo 58 (año 1646), f. 95. 
en 1655 de sueldos y gastos que pagaba de forma ordinaria la hacienda local se apuntaba:

tiene esta ciudad tambor mayor y otros tambores para tocar las caxas de guerra de las diez y seis compañias de la milicia cuyos salarios inportan dos mil y ducientos reales ${ }^{16}$.

En efecto, las solicitudes de este tambor mayor para que el ayuntamiento le librase su salario dejaron su rastro en la documentación capitular de estos años ${ }^{17}$.

Pese a todo, hubieran tenido o no los tambores una vinculación laboral continuada con el ayuntamiento a lo largo del siglo XVI, lo cierto es que éste sufraga diversas partidas de dinero para el vestido y adorno tanto de los propios instrumentos como de sus músicos. Ejemplos: en septiembre de 1535 se acuerda traer ciertos reposteros para los atabales. Lo mismo sucede en 1567. En 1558, se solicita proveer como se hagan los vestidos y lybrea para los atambores y pifaro de la gente que la ciudad haze para servir a su magestad. O cuando en 1594 vinieron de Cádiz y el puerto siete u ocho atambores a la reseña que se hiso de la ynfanteria el segundo día de pascua del espiritu santo, los cuales venían muy maltratados, se les vistió de ropillas y calsones $^{18}$. Todo ello evidencia el marcado carácter heráldico que ostentaban estos músicos al servicio de la Ciudad ${ }^{19}$, tanto en actos ceremoniales como en alardes de guerra.

\subsection{Trompetas}

Junto con el atabal y el tambor, el trompeta se liga desde antiguo tanto al contexto urbano como al militar no como intérprete de música, propiamente dicha, sino como encargado de enfatizar la presencia o anuncios de la autoridad, en este caso de la concejil, mediante avisos acústicos con una mayor o menor complejidad interpretativa. A esta función se debieron de dedicar Pedro García, "trompeta del Concejo" que testaba en 1414 y el trompeta que aparece anotado en las cuentas del municipio de $1482^{20}$.

Esta función de representación municipal, que se acompañaba usualmente de la presencia de la percusión, fue adquiriendo un mayor cariz ceremonial con el auge de la vida urbana durante el siglo XVI. Los instrumentos se hacen más complejos, más musicales por así decirlo, y el número de trompetas va a ir así en aumento, para poder, de ese modo, "hacer música", como dirá el veinticuatro Nuño de Villavicencio en 1550. Hacia 1540 se introduce el uso de la trompeta bastarda

16. AHMJF, sec. I, Actas Capitulares, tomo 63 (años 1655-1656), f. 236.

17. AHMJF, sec. I, Actas Capitulares, tomo 41 (años 1611-1612), f. 1089v.; tomo 42 (16131614), f. 1115v-1116; tomo 44 (1618-1620), f. 1144v.; tomo 48 (1629-1631), f. 906v.-907.

18. AHMJF, sec. I, Actas Capitulares, tomo 14 (años 1535-1539), f. 79; AHMJF, sec. I, Actas Capitulares, tomo 23 (años 1567-1568), f. 486; Actas Capitulares, tomo 18 (años 1556-1558), f. 148; AHMJF, sec. I, Actas Capitulares, tomo 34 (años 1593-1594), f. 410.

19. Al respecto de este tipo de función representativa o heráldica: Carreras 2005, p. 40.

20. Abellán 1997, pp. 112, 125; Martín Gutiérrez 1996, pp. 188-189. 
entre los trompeteros que trabajaban para la ciudad de Jerez. En 1541, se insiste en cabildo que los trompeteros utilicen este tipo de trompetas de mayores posibilidades musicales y para unirse a conjuntos polifónicos y, por tanto, al contrario que las trompetas naturales o italianas, más cercanas al ámbito ceremonial que al militar $^{21}$. Un instrumento al que parece que no estaban muy habituados los trompetas municipales, pues el veinticuatro Jerónimo Dávila anunciaba a sus compañeros de escaño que por servir a la ciudad dará una trompeta que tiene bastarda para en que los trompetas se abezen a tañer ${ }^{22}$. Una noticia que asimismo habla de la presencia de la música dentro de las casas de la nobleza local.

El cabildo era el propietario de los instrumentos y, como tal, responsable de su suministro, conservación y mantenimiento. Cinco ducados costaron cada una de las cuatro trompetas bastardas que el cabildo mandó comprar en $1549^{23}$. En el asiento o contrato que se hacía cada vez que un trompeta o compañía de estos entraba a servir al ayuntamiento, los músicos quedaban obligados a hacer fianzas no sólo para asegurar que cumplirían con su contrato sino que asimismo devolverían los instrumentos que se les entregaban ${ }^{24}$.

El carácter representativo o heráldico que tenían los tambores también lo poseían los trompetas. En 1535 se acordó que las trompetas se guarnecieran con reposteros de damasco. Esta función se extendía igualmente a los propios instrumentistas: en 1567 los capitulares acordaron que los trompetas debían llevar $s u$ librea de paño de las colores de la Ciudad que son azul y blanco porque al abtoridad desta no conviene que vayan los trompetas con capas pintas rotas tañendo. Y asimismo, se dijo:

que en la fiesta y proseçión general que se hizo por el buen alumbramiento que tubo la reyna nuestra señora fueron sirviendo estas trompetas en la proseçion las quales trompetas por estar rotas e mal adereçazadas no pudieron servir ${ }^{25}$.

\subsection{Ministriles}

Hasta 1576 la documentación habla principalmente de "trompetas" cuando se refiere a los músicos que mantenían una relación laboral estable con el ayuntamiento. Incluso, cuando en 1562 se concierte los servicios de la compañía de Diego Rodríguez, que se presentó a la ciudad como ministril, el asiento que se le

21. Sobre las diferentes posibilidades y funciones sonoras de la trompeta bastarda o española frente a las trompetas italianas: Andrés 2009, pp. 443; Bejarano Pellicer 2013, pp. 234-235; Robledo 2000, pp. 173-186.

22. AHMJF, sec. I, Actas Capitulares, tomo 14 (años 1535-1539), ff. 81, 84, 363; AHMJF, sec. I, Actas Capitulares, tomo 15 (años 1541-1544), ff. 170, 171v.

23. AHMJF, sec. I, Actas Capitulares, tomo 16 (años 1548-1550), f. 113.

24. AHMJF, sec. I, Actas Capitulares, tomo 20 (años 1562-1564), ff. 284-286; AHMJF, sec. I, Actas Capitulares, tomo 21 (años 1565-1561), f. 670.

25. Por este motivo se pedirá que los instrumentos fuesen arreglados y que se saque el tafetán que fuere menester para las banderas de las trompetas: AHMJF, sec. I, Actas Capitulares, tomo 23 (años 1567-1568), f. 485. 
hace fue para tocar las trompetas de la ciudad ${ }^{26}$. Esto no quiere decir que el cabildo municipal jerezano no hubiera contratado hasta entonces, aun fuera puntualmente, los servicios de ministriles ${ }^{27}$. Una primera referencia documental se encuentra en las actas capitulares del 1 de febrero de 1549. En esa fecha se recibe el visto bueno del provisor del arzobispado para que las fábricas de las parroquias jerezanas aportasen una asignación para el pago de los ministriles. Con posterioridad a esta carta encontramos la orden del ayuntamiento dada en el cabildo del 27 de febrero para que tanto los trompetas como los ministriles municipales acudieran a la posada del señor corregidor para una fiesta de toros que se iba a celebrar. Semanas después el comendador mosén Diego de Valera solicitaba los servicios de los músicos. En el día 3 de abril siguiente, fueron los propios ministriles desta cibdad los que pedían licencia para vysytar a los señores de la comarca por no aver al presente en que servir ${ }^{28}$.

Salvando ese breve periodo en el que Jerez contó con ministriles y trompetas a su servicio, no es, sin embargo, hasta julio de 1576 cuando la documentación capitular empiece a referirse únicamente a ministriles, lo que da indicio de que estos habían sustituido a los trompetas como únicos instrumentistas de la ciudad, quizás como un elemento más dentro de la política de renovación integral de la imagen de la ciudad que el cabildo estaba llevando en aquellos años y cuyo máximo exponente eran las nuevas y ostentosas casas capitulares. En Sevilla, sin embargo, el ayuntamiento contará simultáneamente con un grupo de trompetas y otro de ministriles ${ }^{29}$. Las trompetas que reseñará la documentación capitular a partir de ahora son ajenas a la copia de ministriles y su aparición se relaciona con concretos contextos militares ${ }^{30}$.

Estos ministriles que sustituían al antiguo conjunto de trompetas municipales hay que identificarlos con el grupo de chirimías que había entrado al servicio de la iglesia mayor colegial en 1574 y que, como veremos, cofinanciaban ambos cabildos $^{31}$. Al frente de ellos se encontraba Antonio Romero ${ }^{32}$. Es él quien firma, en nombre de sus compañeros, la mayoría de los distintos memoriales que los músicos remiten al cabildo municipal desde el referido año de 1576 hasta los úl-

26. AHMJF, sec. I, Actas Capitulares, tomo 20 (años 1562-1564), 253, 284-286, 463.

27. Estaban constituidos, entre otros, por la chirimía, la corneta, el bajón, todos instrumentos de madera, y por el sacabuche, instrumento de metal que permitía tocar todas las notas de la escala cromática. Por su sonoridad permitían realzar las distintas ceremonias celebradas en lugares abiertos. Su repertorio era de tres tipos: primeramente, el vocal, es decir, doblar o sustituir las distintas voces corales. El segundo, el puramente instrumental, derivado del vocal y cuyo principal atractivo era la improvisación de los intérpretes como solistas. Y finalmente, el repertorio de danzas cortesanas (Ruiz Jiménez 2000, p. 93; Astruells Moreno 2005, p. 29).

28. AHMJF, sec. I, Actas Capitulares, tomo 16 (años 1548-1550), ff. 85, 113, 132, 354v.

29. Bejarano Pellicer 2013, pp. 306-314.

30. AHMJF, sec. I, Actas Capitulares, tomo 31 (años 1587-1588), ff. 180, 509, 918v.; tomo 32, (años 1591-1592), ff. 220, 608.

31. Repetto Betes 1980, p. 27.

32. Sin embargo, el primer memorial dado por los ministriles en ese mismo año de 1576 lo encabeza Juan de Saravia: AHMJF, sec. I, Actas Capitulares, tomo 26 (años 1575-1577), f. 426. 
timos del siglo $\mathrm{XVI}^{33}$. Por una escritura de 1588 conocemos los nombres de los otros ministriles que formaban la copia por aquellas fechas. Además de Antonio Romero, la copia la completaban Andrés Sedano, Juan de Torres, Diego Sedano y también actuaría con ellos un hijo de Sedano, Gonzalo Sedano. Un año antes había fallecido Francisco de Villena, quien también habría formado parte de la copia ${ }^{34}$.

Contadas son las ocasiones en la que documentación aporta información concreta sobre los instrumentos que esta copia de ministriles tañían para el cabildo. Por ejemplo, en 1613, cuando los regidores debatan acerca de la conveniencia de dar una ayuda de 100 reales para que los ministriles comprasen una caja de flautas usando el dinero que no se había gastado en la fiesta del Corpus de ese año.

Sobre el sacabuche tenemos una interesante petición que realiza en 1617 el ministril Diego Sedano:

e estudiado y aprendido el tocar sacabuches para servir a vuestra señoría en aviendo oportunidad e porque yo quiero desde luego hacerlo para que en abiendo bacante entre a servir de tal ministril con el dicho instrumento de sacabuches que es el más ynportante de toda la copia ${ }^{35}$.

La importancia del sacabuche, evolución de la trompeta bastarda y antecesor directo del trombón de varas moderno aunque de sonido más dulce y aterciopelado, se descubre cuando en 1581 el también ministril municipal Andrés Sedano -abuelo de Diego Sedano- mande a su hijo Gonzalo a Sevilla -a la sazón tío de Diego-, a estudiar este instrumento ${ }^{36}$. De aquí cabría deducir que esta copia de ministriles no había contado en origen con este instrumento ${ }^{37}$ y que Andrés Sedano como estrategia para afianzar la posición familiar dentro de la copia municipal no escatimase esfuerzos para ofrecer los mejores servicios. Posiblemente Diego Sedano aprendiese a tocar el sacabuche en el ámbito familiar.

En otras ocasiones no es el instrumento sino la voz o tesitura lo que se reseña. En este sentido, es interesante la petición que hace al cabildo jerezano Miguel de Torres Hinojosa en 1630. Se presentaba como ministril tiple de la copia municipal

33. Algunos de estos memoriales: AHMJF, sec. I, Actas Capitulares, tomo 26 (años 1575-1577), f. 553 tomo 29 (1581-1584) f. 1150; tomo 29 (1585-1586), f. 403, 514; tomo 33 (1591-1592), f. 262v., $557,743,817,851,918$.

34. APNJF, tomo 848 (oficio 1, año 1588), 9 de junio. La viuda de Villena casó con el ministril Diego Sedano: APNJF, Tomo 840, oficio 13, año 1587, ff. 102 r-v, 534-539, 548, 773. En 1596, los hijos menores de Villena, Francisco y Sebastián, de 16 y 14 años respectivamente, firmaban escritura para nombrar curador judicial ad litem para poder ejercer y aprender "el arte de ministril en esta ciudad, en la de Sevilla o qualquier otra parte": APNJF, oficio 13, año 1596, f. 249v. Diego Sedano era hijo de Diego Rodríguez Sedano, quien está documentado entre 1585-86 como ministril al servicio del VII duque de Medina Sidonia: AHDJF, Matrimonios, San Miguel, libro 1, agosto de 1587; Gómez Fernández 2017, p. 428.

35. AHMJF, sec. I, Actas Capitulares, tomo 43 (años 1615-1617), f. 940v.

36. APNJF, tomo 735, (oficio 14, 1581), 27 de febrero, ff. 233v.-234. Sobre la genealogía de los Sedano: APNJF, tomo 848, (oficio 1, 1588), 9 de junio; AHMJF, sec. I, Actas Capitulares, tomo 39 (años 1606-1608), f. 1124v.; tomo 43 (año 1615-1617) ff. 940v.-941.

37. En una escritura de 1588, los componentes de la copia municipal se autodenominan "músicos de chirimías": APNJF, tomo 848, (oficio 1, 1588), 9 de junio. 
y decía que, según antigua costumbre, al instrumentista que tocaba esta voz se le libraba veinte ducados más de salario que a las otras plazas, respecto de su mayor trabaxo $^{38}$. Por dicha petición sabemos que el referido Antonio Romero, que dirigió durante más de cuatro décadas la copia de ministriles municipales, también ocupó la misma plaza. En ese mismo año de 1630 se recibió como ministril a Antonio Pereira entrando igualmente para ocupar la plaza de tiple. También en 1630, Domingo Pereira llegó a Jerez para oponerse a la plaza de sacabuche. Fue recibido para servir la vos de contrabaxo ${ }^{39}$. Del longevo Andrés Sedano sabemos que fue ministril tenor ${ }^{40}$.

Desde el último cuarto de siglo XVII desaparece de la documentación capitular jerezana las referencias a ministriles al servicio del ayuntamiento. Este es un fenómeno de carácter general, pues de igual manera sucede en otros lugares, caso de Sevilla o de Sanlúcar, y que se puede explicar tanto por la falta de financiación como por nuevas modas musicales ${ }^{41}$. A partir de 1700 comienza a aparecer en la documentación los clarineros como músicos municipales en Jerez ${ }^{42}$.

\subsection{Mecenazgo y contratación de capillas de música}

El cabildo jerezano mantiene durante todo este periodo una relación que estará a mitad de camino entre el mecenazgo y la contratación de servicios con la capilla musical de la Colegial ${ }^{43}$. Aunque las polémicas con sus posteriores concordias por cuestiones de ceremonial suscitadas entre ambos cabildos pueblan la documentación capitular de esos siglos, esto no fue obstáculo para que ambas corporaciones colaboraran en un asunto nada secundario, como era la provisión de músicos. Un testimonio de ello consta en un cabildo municipal de 1553 donde los canónigos solicitaron una ayuda para el maestro de capilla desa iglesia, en atención a la pobreza que padecía el maestro y a su grande suficiencia e abilidad. Gracias a esa ayuda podría sustentarse juntamente con lo que tiene de las iglesias e visto el pro e utilidad del dicho maestro. Pese a la oposición de algún veinticuatro que consideró excesiva la cantidad, se acordó librar 5.000 maravedíes anuales para el dicho

38. AHMJF, sec. I, Actas Capitulares, tomo 48 (años 1629-1631), f. 760v. Quizá porque a estas voces se les destinaban la tarea de realizar las glosas o ornamentaciones improvisadas sobre piezas polifónicas. Véase: Ruiz Jiménez 2000, pp. 593-597. Asimismo, hay que tener en cuenta que instrumentos de registro tiple como la corneta, adquieren un papel predominante desde finales del XVI como solistas y concertante como acompañamiento de coros y órgano en piezas religiosas: Ruiz Jiménez 2004, p. 228.

39. AHMJF, sec. I, Actas Capitulares, tomo 48 (años 1621-1623), ff. 760, 893-894.

40. AHMJF, sec. I, Actas Capitulares, tomo 45 (años 1621-1623), f. 1426.

41. Daza Palacios 2009, p. 166; Bejarano Pellicer 2013, pp. 285-286.

42. Durante todo el XVIII, Jerez contó con el servicio de dos clarineros, a los que se sumaban en ocasiones especiales bandas militares de música o componentes de la capilla musical de la iglesia mayor: AHMJF, sec. I, Actas Capitulares, tomo 126 (1786), ff. 53, 96. AHMJF, sección Archivo Histórico Reservado, Cajón 8, Número 15, f. 29; AHMJF, sec. VI, Protocolo, Fiestas, Solemnidades, legajo 301, expediente 8961 .

43. Era una práctica que también se daba en Sevilla: Bejarano Pellicer 2013, pp. 351-355. 
maestro de capilla por un tiempo de cuatro años, con la condición de que resida en la iglesia e en la fiestas de la ciudad todo el tiempo ${ }^{44}$.

Otra referencia a que la hacienda de la iglesia mayor no andaba muy holgada por aquellos años para gastos en músicos es la petición hecha en 1558 por el veinticuatro Juan Gaitán de Trujillo. El regidor expresaba la necesidad de que ayuntamiento buscara cantores para la fiesta de San Sebastián y que se les pagase porque la iglesia mayor no los tiene. Además pedía que vayan las trompetas que la ciudad lo provea de manera que la fiesta se haga con toda solemnidad ${ }^{45}$.

En 1622, el maestro de capilla de la Colegial Bartolomé Méndez, en nombre de los demás cantores, requería al cabildo su sueldo por haber asistido a la fiesta de la Concepción. Sin dar razones, el ayuntamiento negó el pago ${ }^{46}$.

Este patronazgo municipal sobre la capilla de música de la iglesia colegial perdura hasta mediados del siglo XVII, al menos en algunos aspectos. Por ejemplo, en 1656 el maestro de capilla solicitaba los 200 reales de ayuda de costa para los gastos del adereço de los seises que salen a danzar el día del corpus, así como por el trabaxo de los villançicos que se cantan en la prosesión del dicho día y para darles un refresco a los dichos cantores, de los que se expresaba que eran pobres ${ }^{47}$.

En otras ocasiones, el municipio contrataba de manera particular la capilla de música de la Colegial de San Salvador para ciertos actos ceremoniales, como fueron, por ejemplo, las exequias de la reina Isabel de Borbón. En 28 de abril de 1645, Francisco de Hiada y Corral maestro de la capilla de la Iglesia mayor desta ciudad daba carta de pago de haber recibido 88 reales por la ocupación y trabajo que en coro de la dicha iglesia tubo y sus compañeros en oficiar las misas y demás esequias funerales por ayuda de costa ${ }^{48}$.

En las exequias de Felipe IV que acogió la iglesia mayor el domingo 24 de enero de 1666 dirigió la capilla de la Colegial Andrés Botello de Azanbuja ${ }^{49}$. En 22 de enero el maestro firmaba la carta de pago de los 300 reales por la asistencia que él y su capilla había de tener el día de la vigilia, misa y sermón del día siguiente, por los demás sufragios de las citadas honras que estaban por hacer y celebrar, así como por las asistencias a los responsos de las parroquias y conventos ${ }^{50}$.

Pero también existieron contratos menos eventuales con estas capillas musicales. Tal sería el que propusieron los capitulares en 1654 para que la capilla de música de la iglesia colegial de San Salvador o la de la iglesia parroquial de San Miguel asistiesen a cantar las salves y letanías que todos los sábados se hacían ante el quadro de nuestra señora de la limpia y pura concepción en las casas de su

44. AHMJF, sec. I, Actas Capitulares, tomo 17 (años 1550-1553), f. 623.

45. AHMJF, sec. I, Actas Capitulares, tomo 18 (años 1556-1558), f. 125v.

46. AHMJF, sec. I, Actas Capitulares, tomo 45 (años 1621-1623), f. 627v.

47. AHMJF, sec. I, Actas Capitulares, tomo 61 (años 1652-1653), f. 1169.

48. AHMJF, sección Archivo Histórico Reservado, Caja 3, Número 16, ff. 322, 328.

49. Ejerció el cargo hasta 1672: Reppeto Betes 1980, pp. 66-67.

50. AHMJF, sección Archivo Histórico Reservado, Caja 3, Número 15, f. 101v. 
ayuntamiento, de manera que se diera más solemnidad al culto ${ }^{51}$. Una contratación que asimismo se repetía en la procesión anual del Corpus ${ }^{52}$.

\section{EVOLUCIÓN DE LA PLANTILLA DE MÚSICOS MUNICIPALES JEREZANOS}

Es evidente o lógico de pensar que el número de músicos que formarían la plantilla municipal tuvo que estar en relación directa con la constante búsqueda de prestigio por parte del ayuntamiento, con independencia, en no pocas ocasiones, de sus posibilidades económicas. Del único trompeta que consta en las cuentas del concejo en 1482 se pasa, ya en el siglo XVI -1541- a que, al menos, se contaba con tres trompetas asalariados ${ }^{53}$. De ahí pasamos al cabildo del 29 de mayo de 1548 en el que se contrataba a Juan de Madrid y a Juan Sánchez, dos oficiales trompetas que faltan para sumar quatro trompetas ${ }^{54}$. Cuatro trompetas estaban al servicio del cabildo hispalense, número que con algunas fluctuaciones mantendrá hasta el siglo siguiente, compaginándolas con una copia de ministriles cuyos componentes oscilan entre los cuatro y los seis a lo largo del mismo periodo ${ }^{55}$.

Sin embargo, el número de estos trompetas no fue constante, ya que fluctúa de un año a otro debido a causas o contingencias que no podemos establecer con certeza. En 1550, el veinticuatro Nuño de Villavicencio expuso ante sus compañeros regidores que no hay más que dos trompetas y que dos trompetas no hacen musyca que la ciudad vea que se busque trompetas. Tras ello, el también veinticuatro Pedro de Vargas, secundando a su compañero Francisco de Trujillo, tomaba la palabra para recordar a sus colegas regidores que existía una provysyón regia que estipulaba el número de trompetas que esta ciudad a de rebcibir y tener e los salarios que sea justo que se le den, aclarando que la voluntad de su magestad fue de no dar más salarios. El punto final lo pondrá el alcalde mayor que sugerirá a los regidores que suplicaran al rey a través de su letrado en la corte la licencia para la contratación de más trompetas ${ }^{56}$.

Por la petición que hará en 1565 el trompeta Francisco de Salcedo sabemos que tanto él como Juan Izquierdo y Juan Buy, en compañía, habían servido al cabildo jerezano por tiempo de doze años en este oficio de trompetas hasta que se les canceló el contrato ${ }^{57}$. Un número de trompetas que confirma la contratación de la compañía del ministril sevillano Diego Rodríguez en 1562 donde los capitulares justificarán la contratación de estos cuatro instrumentistas afirmando que fasta agora las trompetas que esta cibdad tenya heran tres y serbyan mal ${ }^{58}$.

51. AHMJF, sec. I, Actas Capitulares, tomo 62 (años 1654), ff. 1099v. - 1100.

52. AHMJF, sec.VI, Protocolo, Fiestas, Solemnidades, Legajo 303, expedientes 9021-9026.

53. AHMJF, sec. I, Actas Capitulares, tomo 15 (años 1541-1544), f. 170.

54. AHMJF, sec. I, Actas Capitulares, tomo 16 (años 1548-1550), f. 14.

55. Bejarano Pellicer 2013, pp. 307-314.

56. AHMJF, sec. I, Actas Capitulares, tomo 17, ff. 287v.-288v. 307.

57. AHMJF, sec. I, Actas Capitulares, tomo 21 (años 1565-1561), f. 699.

58. AHMJF, sec. I, Actas Capitulares, tomo 21 (años 1565-1561), ff. 284-286. 
Los dichos Salcedo, Izquierdo y Buy volvieron a estar al servicio de la ciudad, al menos hasta 1567; en ese año es Francisco de Salcedo quien dirige en nombre de los trompetas los memoriales y peticiones al ayuntamiento ${ }^{59}$. En 1576, en cambio, lo será Francisco de Saravia, ya en nombre de la copia de ministriles. Sin embargo, en ninguno de ambos casos se indicó a cuantos compañeros de oficio representaban ${ }^{60}$.

En la petición que en 1625 el cabildo remite al Real Consejo para la prorrogación de la facultad para pagar de los Propios a la copia de ministriles se declaraba que de tiempo inmemorial a esta parte abia tenido sinco ministriles. Una escritura notarial de 1588 señala a cuatro ministriles, si bien es verdad que Saravia no consta ya como miembro de la copia ${ }^{61}$. En 1608, la copia de ministriles desta cibdad la formaban Diego Sedano, Andrés Sedano, Gonzalo Sedano y Antonio Romero. Diego Sedano, hijo de Gonzalo Sedano, había entrado en 1606 para cubrir la plaza de Juan de Torres que acababa de fallecer. Por tanto, hay que entender que a principios de siglo seguían siendo cuatro.

La cifra de ministriles se incrementó a cinco instrumentistas en la década siguiente de forma efectiva cuando el cabildo reciba como ministril "supernumerario" a Miguel de Torres Hinojosa en 1615 con el mismo salario de treinta mil maravedíes que tenían los demás, pese al desacuerdo del veinticuatro Jerónimo Dávila que recordaba que la hacienda municipal no podía atender el pago de otro sueldo. La situación se repite en 1617 con Diego Sedano, hijo del homónimo ministril municipal. Esta vez, sin embargo, los capitulares no fueron tan complacientes. Justificaban su contratación por considerar que: el dicho diego sedano y su padre an servido el oficio de ministril y la destressa con que el dicho diego sedano toca el sacabuche ${ }^{62}$. Además, no se le daría sueldo alguno hasta que vacase una plaza dentro de la copia. Así sucede en octubre de 1623 cuando Cristóbal de Palacios entre en la copia con esas condiciones por estar acomodado en la música de la iglesia mayor e porque Andrés sedano ministril tenor está muy viejo e impedido. Aunque se acordó darle una ayuda de costa de 30 ducados para casa y ropa el veinticuatro Rodrigo de Morales se opuso con una interesante declaración: porque sabe que este hombre está contento con la futura sucesión sin pedir ynteres ni dádiva y porque la hacienda municipal estaba tan acabada. Palacios ocupará la plaza de ministril municipal en $1625^{63}$. Con esta acción los hijos de los viejos ministriles municipales, junto con otros músicos que, como Palacios, llegan a Jerez a labrarse un futuro ejerciendo su oficio, se aseguraban un empleo estable al servicio del ayuntamiento jerezano.

59. AHMJF, sec. I, Actas Capitulares, tomo 23 (años 1567-1568), f. 485.

60. AHMJF, sec. I, Actas Capitulares, tomo 26 (años 1575-1577), ff. 426, 553, 973.

61. Eran: Antonio Romero, Juan de Torres, Andrés Sedano y Diego Sedano: APNJF, tomo 848, (oficio 1, 1588), 9 de junio.

62. AHMJF, sec. I, Actas Capitulares, tomo 43 (años 1615-1617), ff. 110v.-111, 114, 940v.-941. f. 835 .

63. AHMJF, sec. I, Actas Capitulares, tomo 45 (años 1621-23), f. 1426; tomo 46 (años 1624-25), 
Unas décadas más tarde, en plena época de la fiesta barroca, en concreto en 1646, ya se habían incrementado en seis los ministriles asalariados ${ }^{64}$. Sin embargo, las circunstancias cambiarán a partir de entonces. En un contexto general de crisis política y de inflación y depreciación monetaria, la reducción del sueldo que recibían los citados seis ministriles, debido a tener que compartir con un compañero más la misma asignación que el ayuntamiento había estado destinando hasta entonces para cinco, hará que mayoría de ellos abandonen el empleo. Meridianamente claro lo dejó expresado en 1654 el que por aquellos años se descubre como cabeza visible de los ministriles jerezanos, Esteban de Torres Hinojosa: por ser tenuo (sic) el salario se fueron en diferentes tiempos ${ }^{65}$. Este mismo hecho fue denunciado unos años antes, en 1648, por el veinticuatro Francisco Esteban Suárez de Figueroa, quien exponía que oy no sirven sino tres o cuatro $^{66}$. La merma en el conjunto de ministriles hizo que en 1652 a instancias del citado Esteban de Torres se contratara a dos nuevos ministriles: los hermanos Juan y Francisco de Aguilar, que casualmente pasaban por Jerez con destino a la vecina ciudad del Puerto de Santa María. De esta manera se completaba de nuevo el cupo de cinco ministriles que solía tener el cabildo a su servicio ${ }^{67}$. Pese a todo, algunos se irían años antes, como fue el caso del sacabuche Domingo Pereira, que hacia 1637 marcha a Nueva España en busca mejores horizontes profesionales en las catedrales de México y Puebla $^{68}$.

Sin embargo, la situación no mejoró: cuatro años después, 1656, sólo quedaban al servicio del ayuntamiento Torres Hinojosa junto a Pedro Fernández y Luis Falcón. En sus nombres, Torres relataba al cabildo la necesidad que tenemos de un compañero que tocara sacabuche. Igualmente informaba que habían hecho diligencias para buscarlo mediante los quales a venido a esta ciudad francisco de los ríos miranda persona muy abil y suficiente. No deja de ser llamativas las gestiones de Torres y el tono con que concluye su petición: suplicamos lo admita en su servicio y mande se le asiente el salario que a los demás y en todo imploramos el auxilio de vuestra señoría ${ }^{69}$. Es de suponer que los ministriles temiesen que, ante la falta de instrumentistas, el cabildo acordara un nuevo contrato con otro grupo de ministriles, como ya había sucedido en el pasado.

Todo esto en lo que concierne a los músicos de instrumentos de viento, en cuanto a los tambores, ya se indicó que a mediados del siglo XVII existía la figura

64. AHMJF, sec. I, Actas Capitulares, tomo 58 (años 1646-1647), ff. 124v.-125.

65. AHMJF, sec. I, Actas Capitulares, tomo 62 (año 1654), f. 350r.

66. AHMJF, sec. I, Actas Capitulares, tomo 59 (años 1648-1649), f. 424.

67. AHMJF, sec. I, Actas Capitulares, tomo 61 (años 1652-1653), ff. 312-312v.

68. En 16 de febrero de 1637, el ministril Cristóbal Muñoz se presentaba ante el cabildo relatando que yo e venido a esta ciudad para ocupar la plaza de sacabuche que ussava domingo Pereira: AHMJF, sec. I, Actas Capitulares, tomo 56 (años 1648-1649) f. 545v. Planteamos que Domingo de Pereira fuera el homónimo sacabuche que en las décadas centrales del siglo XVII se encuentra en tierras mejicanas: Murrell Stevenson 1974, pp. 46, 50, 51, 56.

69. AHMJF, sec. I, Actas Capitulares, tomo 63 (años 1655-1656), f. 1146. Quizá fuera esta búsqueda de compañeros la que hizo que Andrés Sedano se obligara en 1582 a pagar ciertas deudas que Baltasar Pérez "múçico" tenía con el jurado de Toledo Sancho de Moncada: APNJF, tomo 745 (oficio 14, 1582), f. 578 
del tambor mayor y otros tambores que asistían a las dieciséis compañías de infantería de la ciudad, pero no podemos dar una cifra segura de su número ${ }^{70}$.

\section{GESTIÓN MUNICIPAL DE LOS MÚSICOS A SU SERVICIO}

Los músicos se vinculaban con el cabildo de dos maneras principales: una era la de ser retribuidos por trabajo realizado y la otra la vinculación por medio de un asiento o contrato. En estos asientos, por parte de la Ciudad comparecían los capitulares diputados entre cuyas competencias estaba la gestión de los músicos municipales. En uno de los primeros de estos asientos de que tenemos constancia documental, fechado en 1562, la diputación sobre la que dependían los músicos era la denominada como de Iglesias. Sin embargo, como arrojan los distintos acuerdos municipales, la gestión directa de los músicos municipales se relaciona especialmente con las diputaciones de Alarde o Guerra y con la de Fiestas. Se definen, así, los ámbitos en los que la música tenía presencia para el cabildo municipal jerezano. Con el gradual incremento de la actividad ceremonial que tiene lugar a nivel general en la sociedad española durante los siglos XVI y XVII, la diputación de Fiestas es la que va a ir tomando mayor preeminencia en la gestión de las cuestiones relativas a los músicos. En cualquier caso, será el pleno municipal quien dicte la resolución definitiva de los distintos asuntos, siempre que entren dentro de su jurisdicción. Y en última instancia el Real Consejo, quien debía aprobar las licencias para que la hacienda local sufragara este asunto.

\subsection{La contratación de los músicos}

A la primera de las situaciones citadas -retribución por trabajo realizado- parece que se ajustaban los servicios de los tambores que trabajan para el cabildo xericiense, posiblemente por la circunstancia de ser instrumentistas para los que la práctica musical se constituía como una actividad laboral secundaria.

Los trompetas primero y, posteriormente, los ministriles sí tuvieron una vinculación laboral más reglamentada u oficial con el ayuntamiento. La documentación revela que esta relación se establecía mediante un asiento o contrato. Desde mediados del siglo XVI se estaba generalizando a lo largo y ancho de toda España la contratación por parte de instituciones civiles y religiosas y también por parte de particulares de los servicios de músicos como medio de rentabilizarlos ${ }^{71}$. Estos asientos no tenían una duración indefinida sino que estaban sujetos a un periodo de tiempo determinado, al cabo del cual el cabildo se planteaba si seguir con la misma copia de músicos o si hacer otra contrata económicamente más ventajosa.

Sin embargo, estos contratos podían ser incumplidos por parte de los músicos, como sucede a principios de 1550. En esta fecha, el sacabuche Juan Bautista aban-

70. AHMJF, sec. I, Actas Capitulares, tomo 63 (años 1655-1656), f. 236.

71. Bejarano Pellicer 2013, p. 230; Ruiz Jiménez 2004, pp. 207-208. 
dona a sus compañeros y se vuelve a Sevilla incumpliendo las obligaciones contraídas. Denunciado el hecho por Diego de López de Mora ministril mayor de la música de cherimias de la ciudad, se harán gestiones para traerlo de nuevo a Jerez. El sacabuche se negó a volver. Será denunciado ante la justicia de Sevilla, pero el ministril había huido de la ciudad. Al no poder recomponer la copia, el ministril mayor marchó a Toledo dejando sin pagar las deudas de las gestiones, las cuales se le desquitaron del salario que el ayuntamiento le adeudaba ${ }^{72}$. El absentismo de los ministriles fue algo consustancial a un oficio con tanta movilidad geográfica e institucional ${ }^{73}$.

En otros casos, es el ayuntamiento quien rescinde el contrato a los músicos, así sucede en septiembre de 1562 cuando se despide al trompeta Francisco de Salcedo y a sus otros dos compañeros para contratar a la compañía de ministriles formada por el sevillano Diego Rodríguez y sus tres hijos ${ }^{74}$. Aunque el asiento con Rodríguez fue por seis años, en enero de 1565 el cabildo volvió a contratar a Salcedo y a sus compañeros, quienes habían regresado a la ciudad con sus familias solicitando ser contratados nuevamente ${ }^{75}$. Ignoramos quien incumplió aquí el contrato.

Algún tipo de desavenencia hubo de existir entre capitulares y ministriles en 1643; en 12 de enero de 1644 se formalizó un asiento con una copia ajena a la municipal. Pedro Ortiz vesino de la ciudad de Arcos de la frontera por sí y en nombre de otros dos ministriles sus compañeros otorgaba un contrato por un tiempo de cuatro años ${ }^{76}$. Dos años después, los antiguos ministriles (Miguel de Torres Hinojosa, Esteban de Torres Hinojosa, Cristóbal Muñoz, Domingo de Rebordero y Antonio de Pereira) remitían un escrito en el que exponían:

Que no hemos seçado de servir a Vuestras señorías En nuestras plaças y oficios de ministriles sin embargo del acuerdo que hizo en el año 43 y continuando nuestro servicio por no a ver sido el ánimo de Vuestras Señorías el de despedirnos ni que dejáramos de servir por tanto atento a lo referido pedimos declare por suspendido el dicho acuerdo y que nuestras plazas corran como antes hasta oy.

Esta extraña situación se soluciona con la firma de nuevo contrato con la antigua copia, aunque entrando en ella el citado Pedro Ortiz ${ }^{77}$.

Estos asientos o contratos se formalizaban ante el escribano de cabildo y usualmente se insertaban en el libro de actas de cabildo ${ }^{78}$. Los plazos de vigencia del contrato podía ir desde los seis años, en que se fija el asiento con la compañía de Diego Rodríguez en 1562, a los diez años y por todo el más tiempo que la ciudad quisiere a su dispossion y voluntad que establece el asiento que se hará con

72. AHMJF, sec. I, Actas Capitulares, tomo 17 (años 1550-1553), ff. 341-341v.

73. Bejarano Pellicer 2013, p. 65-72, 96-107; Ruiz Jiménez 2004, pp. 206.

74. AHMJF, sec. I, Actas Capitulares, tomo 20 (años 1562-1564), ff. 253, 284-287r., 463.

75. AHMJF, sec. I, Actas Capitulares, tomo 20 (años 1562-1564), ff. 253, 284-286, 286-287; Tomo 21 (años 1565-1561), f. 669

76. AHMJF, sec. I, Actas Capitulares, tomo 56 (años 1644), f. 592.

77. AHMJF, sec. I, Actas Capitulares, tomo 58 (años 1646-1647), ff. 124v.-125, 145.

78. Sobre estos contratos en el caso sevillano: Bejarano Pellicer 2013, pp. 271-279. 
los ministriles en $1646^{79}$. Esta dispossion y voluntad del cabildo de mantener en nómina a los músicos cada vez que expiraban uno de estos contratos daba lugar a debates que siempre giraban en torno a cuestiones económicas, debates que no eran, desde luego, privativos únicamente de esta ciudad ${ }^{80}$. Pero ante la dificultad de encontrar músicos y la ineludible necesidad de mantener la crecida actividad ceremonial, rara vez los munícipes votarán en contra de las renovaciones de los asientos.

Punto fundamental de los contratos eran las obligaciones a las que cada parte, músicos y ayuntamiento, se obligaban. Es decir, las tareas de los músicos y el salario que por ellas recibirían. Pero de ambos aspectos nos ocuparemos de manera específica.

Hasta aquí se ha referido a asientos con una copia o grupo de músicos. Sin embargo, también se dieron con músicos de manera individual que venían a cubrir las vacantes que se originaban en la copia ya contratada. Una primera referencia la encontramos en 1541. En este caso, la causa de la vacante fue la muerte de Francisco Santiago, uno de los trompetas. Esto obligó a contratar a Alonso Rodríguez que era sobrino de Antón Rodríguez, compañero de fallecido. Recibirá el mismo salario que se le había estado librando a Santiago ${ }^{81}$. Como se demuestra en los demás casos documentados, el nuevo músico debía aceptar las condiciones del contrato del anterior músico o copia. No obstante, se podía dar el caso, como cuando en 1606 se admita a Diego Sedano, en el que se acordaba que los caballeros diputados de fiestas hagan la escritura y asiento que convenga ${ }^{82}$. Así, cada vacante que se producía en la copia se cubrirá ya por aspirantes que solicitaban ser recibidos en ella, o ya por gestiones del ayuntamiento o de los propios músicos.

\subsection{La capacitación de los músicos contratados}

Para la verificación de la capacitación de los aspirantes sólo intervienen los regidores diputados. No tenemos constancia de una intervención en el "examen" de veedores músicos profesionales. De este modo cuando en 1562 el ministril Diego Rodríguez llegue a Jerez ofreciendo sus servicios, el veinticuatro Lope López de Morla votaba a favor de la contratación exponiendo: que los que sirven a esta cibdad de trompetas no son buenos y razonables y porque al presente a esta cibdad an venydo quatro hombres que sirven de trompetas muy buenos... ${ }^{83}$

Los regidores asumían, pues, tener la capacidad o la "cultura musical" necesaria para discernir las aptitudes de los instrumentistas que eran contratados. Veamos un par de casos que lo ilustran suficientemente bien. El primero resulta del acuerdo que hizo el cabildo en 1608 a petición del ministril Juan Bautista de Heredia

79. AHMJF, sec. I, Actas Capitulares, tomo 20 (años 1562-1564), ff. 286-287; AHMJF, sec. I, Actas Capitulares, tomo 58 (años 1646-1647), f. 145.

80. Sería el caso de Sevilla: Bejarano Pellicer 2013, p. 278.

81. AHMJF, sec. I, Actas Capitulares, tomo 15 (años 1541-1544), f. 170.

82. AHMJF, sec. I, Actas Capitulares, tomo 39 (años 1606-1608), ff. 592v.-593.

83. AHMJF, sec. I, Actas Capitulares, tomo 20 (años 1562-1564), ff. 284-286 
para ser admitido a la vacante dejada en la copia municipal por muerte de uno de sus miembros. Dijeron los capitulares: Se admite y que los señores diputados hagan que el dicho ministril toque para ver si sabe hacer el dicho oficio y sabiéndolo hacer se admita en la forma dich ${ }^{84}$.

El otro ejemplo lo tomamos de las actas capitulares del año 1630 que anota el siguiente acuerdo:

El corregidor dixo que en compañia de los señores don fernando Sacarias de billavicencio y don fernando nuñes de Villavicencio veinte y quatros diputados el sábado próximo pasado examinaron a Antonio de Pereira ministril tiple y les paresio ser diestro que toca bien ${ }^{85}$.

\subsection{Convocatoria de oposiciones}

En ese mismo libro capitular encontramos la única referencia sobre la convocatoria de unas oposiciones para cubrir una vacante en la copia; tras leer la petición de Domingo de Pereira en la que se presentaba como hermano del citado Antonio de Pereira y venido a servir a vuestra señoría en la plaza de ministril que ocupaba Diego Sedano, los capitulares acuerdan que: que dicha plaza se dé por oposición a quien más bien lo hiciere. El asunto se remite a los diputados de Fiestas para que publicasen edictos para el día que pareciere a las ciudades de yglesias catedrales donde más convenga. Es interesante señalar la decisión de despachar el edicto a ciudades con iglesias catedrales, pues denota, una vez más, la falta de estos instrumentistas en Jerez y la seguridad que tenían los capitulares de encontrarlos en el entorno de las capillas musicales catedralicias. No fue muy atractiva la convocatoria, pues terminado el plazo de cinco meses nadie se presentó a opositar a la plaza, por lo que finalmente fue dada a Pereira ${ }^{86}$.

\subsection{Salarios}

Establezcamos, ahora, los pormenores relativos al sueldo que recibían estos instrumentistas musicales, así como su evolución a lo largo del tiempo. Comenzaremos por el trompeta que en 1482 aparecía en las cuentas de la hacienda de Propios del concejo jerezano. Se le asignaba anualmente 3.000 maravedíes de sueldo, cantidad que se libraba de la renta del Noveno del Vino. Comparando este salario con el de los otros empleados municipales se observa que no distaba en demasía de los 3.150 maravedíes del portero de Cabildo, o de los 4.000 que recibían el escribano mayor de cabildo y el relojero. El sueldo de los regidores oscilaba entre los 2.000 maravedíes de los jurados y los 4.000 de los veinticuatros a los 224.000 que anualmente percibía el corregidor ${ }^{87}$.

84. AHMJF, sec. I, Actas Capitulares, tomo 39 (años 1606-1608), f. 1291.

85. AHMJF, sec. I, Actas Capitulares, tomo 48 (años 1629-1631), f. 760, 893-894.

86. AHMJF, sec. I, Actas Capitulares, tomo 48 (años 1629-1631), f. 844.

87. Martín Gutiérrez 1996, pp. 188-189. 
En el asiento del año 1548 con los trompetas Pedro de Madrid y Juan Sánchez, al primero se le asentó un salario anual de seis ducados, unos 2.178 maravedíes. A Juan Sánchez, por su parte, se le asignó 1.000 maravedíes anuales. En el mismo asiento se aumentaba en 1.000 maravedíes el sueldo de Tomás Sánchez, uno de los dos trompetas que tenía la ciudad en aquellos días, con lo que percibiría anualmente 4.000 maravedíes, quizá el mismo sueldo que recibía su compañero Gaspar Sirgado ${ }^{88}$. No se exponen las razones para esta variación en los sueldos entre los compañeros de oficio, ni tampoco cuál era la cuantía total que el Cabildo destinaba para los trompetas. En 1559, Cristóbal de Cruces solicitaba que se le asentase formalmente su empleo de trompeta municipal. El salario se le fijará en 3.000 maravedíes anuales, precisándose que éste era el mismo que el del resto de los trompetas ${ }^{89}$.

Años más tarde, en el asiento con la copia de ministriles de Diego Rodríguez firmado en abril de 1562 la cuantía total de caudal municipal destinado a la contratación de estos músicos fue de 15.000 maravedíes $^{90}$. El reparto de esta cantidad entre Rodríguez y sus tres compañeros parece que tampoco era equitativo; meses después el cabildo recibe una petición de Rodríguez por la que pedía se le libre su salario de trompeta que es synco mil maravedies atento a que lo tiene serbydo ${ }^{91}$.

Sin embargo, en 1565 nuevos trompetas habían sido contratados. Cada miembro de la copia formada por Francisco Salcedo, Juan Buy y Juan Izquierdo recibirá los ya citados 3.000 maravedíes anualmente que constaba por provisión de su magestad $^{92}$.

Este sueldo se libraba normalmente por tercios a lo largo del año, pero las continúas peticiones que daban los ministriles para que se pusieran al día sus salarios, que no difirieren de las que hacían otros empleados municipales, demuestra la impuntualidad de los pagos ${ }^{93}$. Se llegó a momentos verdaderamente críticos como los que se suceden a mediados de la década de los 80 del siglo XVI, quizás por el muy significativo aumento a 420 ducados anuales (157.542 maravedíes) del dinero destinado a pagar los servicios musicales. Para paliar esta situación el ayuntamiento acordará con los ministriles mantener los sueldos mediante algunas de las rentas que componían parte de los ingresos de la hacienda municipal con el fin de dar seguridad a su pago, tales como las de la almona, dehesas o los hacinamientos de las carnicerías ${ }^{94}$.

88. AHMJF, sec. I, Actas Capitulares, tomo 16 (años 1548-1550), f. 14.

89. AHMJF, sec. I, Actas Capitulares, tomo 19 (años 1559-1560), f. 444.

90. AHMJF, sec. I, Actas Capitulares, tomo 20 (años 1562-1564), ff. 286-287.

91. AHMJF, sec. I, Actas Capitulares, tomo 20 (años 1562-1564), ff. 463-463v.

92. AHMJF, sec. I, Actas Capitulares, tomo 21 (años 1565-1561), ff. 669, 167.

93. Sin ser exhaustivos: AHMJF, sec. I, Actas Capitulares, tomo 21 (años 1565-1561), ff. 233v. 463; tomo 22 (año 1566), ff. 27, 120; Tomo 23 (años 1567-1568), f. 964; tomo 26 (años 1575-1577), f. 553; tomo 29 (años 1581-1584) ff. 755, 1150; tomo 29 (años 1585-1586), ff. 65, 150, 403, 514; tomo 33 (años 1591-1592), f. 262v., 557, 851, 918; tomo 39 (años 1606-1608), ff. 769v.-770; tomo 43 (1615-1617), ff. 836-7.; tomo 50 (años 1634-1635), ff. 554v. 630, 645v, 646, 1010; tomo 62 (años 1654), 350r.-v.

94. AHMJF, sec. I, Actas Capitulares, tomo 30 (años 1585-1586), f. 496. AHMJF, sec. I, Actas Capitulares, tomo 28 (años 1581-1584, f. 1150; tomo 30 (años 1585-1586), ff. 134, 150, 193, 354. 
Hacia 1590 los ministriles se habían hecho cargo del arrendamiento del cobro de la renta del Cornado de la Carne. Así podían tener el efectivo directamente y no esperar a que el mayordomo de los Propios les pagara las libranzas. Sin embargo, estas rentas no cubrieron la mayor parte de las veces la totalidad del sueldo. No obstante, en los años en que el impuesto rentaba por encima de éste los ministriles tenían la obligación de devolver la demasía a la hacienda local ${ }^{95}$.

En 1594, la Ciudad (el Ayuntamiento) estaba en mucho aprieto por las deudas y empeños que tenía contraídas, ello dio lugar a que varios veinticuatros fueran diputados para redactar una Reformación de los gastos municipales. Se elabora así un informe en el que se recortaba o se ponía un tope en gastos y personal del ayuntamiento. La reforma no dejó atrás ningún capítulo, desde el sueldo de los regidores a los gastos en fiestas; desde los escribanos de cabildo, los letrados en Granada a los Niños de la Doctrina. El sueldo de los ministriles también fue objeto de "Reformación". Se acordó que no llevarían más salario de lo que montara el valor de la citada renta del Cornado en cada un año, añadiéndose tajantemente: $y$ sino quisieren açetarlo se despidan ${ }^{96}$. Con todo, esta reforma parece que no se pondrá en práctica.

Los ministriles continuarán como arrendadores de estas rentas hasta $1636^{97}$. En ese año y muy posiblemente para evitar fraudes, el ayuntamiento acordaba que fueran los fieles de la carnicería los encargados de ir entregando semanalmente lo recaudado a los ministriles, ajustándose a fin de año lo que había montado la renta, de modo que los ministriles tomasen a cuenta lo que le correspondía de su salario y si la renta hubiera sobrepasado el sueldo, el sobrante debía ser devuelto al mayordomo de Propios $^{98}$. Este mecanismo de cobro queda establecido en los siguientes asientos ${ }^{99}$.

Como gastos procedentes del caudal de Propios, los sueldos de los ministriles debían tener la autorización real. Estas facultades reales tenían un carácter temporal, por lo que al cumplirse los plazos era necesario movilizar a los agentes y procuradores de Jerez en la Corte para lograr su renovación. En las actas de cabildo de 1603 se incluye una de estas reales facultades por la que se prorrogaba por tercera vez la licencia para poder tener ministriles y darles de salario en cada un año cuatroçientos y veinte ducados de vuestros propios y rentas por un tiempo cuatro años (la ciudad la había pedido, sin embargo, por un periodo de diez años) ${ }^{100}$.

La renovación de estas facultades reales ocasionará más de un debate entre los capitulares jerezanos. En el citado cabildo de 1585, se proponía despedir a los ministriles hasta que no se renovase la licencia, remarcándose la dificultosa situación por la que pasaban las arcas municipales. Esta falta de liquidez en las arcas de la

95. AHMJF, sec. I, Actas Capitulares, tomo 43 (años 1615-1617), ff. 836 v.-837.

96. AHMJF, sec. I, Actas Capitulares, tomo 34 (años 1593-1594), f. 436v.

97. En 1611 los ministriles traspasaban el arrendamiento de otra renta -la del almotacenazgoque se les había rematado en 3.955 reales: APNJF, tomo 1146 (oficio 10, año 1611), ff. 201-203.

98. AHMJF, sec. I, Actas Capitulares, tomo 38 (años 1636-1637) ff. 469, 532-532v.

99. AHMJF, sec. I, Actas Capitulares, tomo 58 (años 1646-1647) ff. 124v.-125.

100. AHMJF, sec. I, Actas Capitulares, tomo 38 (años 1603-1605), ff. 392v.-393. 
Ciudad la llevaban sufriendo los ministriles desde meses atrás; sistemáticamente se les había estado negando el cobro de las libranzas de su salario anual ${ }^{101}$.

La enmarañada votación y debate que se suscita entre los capitulares a raíz de la proposición en torno a qué hacer con los ministriles y su sueldo no hace sino venir a demostrar que la música no fue un asunto secundario para los regidores jerezanos. Y el asunto se presentaba complicado. Una opción era reducirles el sueldo. Para ello había que despedirlos y hacer un asiento más económico con los ministriles actuales o con otros. De esta primera opinión era el veinticuatro López de Morla, quien proponía mantenerlos con tal de que el sueldo no subiera de los 60 ducados a cada uno. La otra opción, el despedirlos, era más problemática, pues obligaba a buscar nuevos músicos, lo que era difícil en Jerez, por lo que se haría necesario acudir a otras localidades, en concreto a Sevilla. Para el regidor Ginés de Ávila los ministriles eran cosa conveniente a la ciudad y apuntaba que él habia visto dos veces pedir a su magestad facultad para tenerlos. Además, agregaba, los ministriles que estaban sirviendo eran buenos y están de mucho tiempo en esta ciudad e pasan con el poco salario que se les da y por si fuera poco estaban abezindados e casados. A renglón seguido, Ávila sacará a debate un aspecto interesante sobre la financiación de los músicos municipales: es ayuda que los señores canónigos les façen de dalles trigo y otros salarios y si otros viniesen (otros ministriles) no sabe si ellos (los canónigos) se lo darían ni el prelado daría licencia para que de la fabricas se les diese nada. Hagamos una parada en este punto.

La financiación conjunta o paralela de un mismo grupo de ministriles entre cabildos municipales y eclesiásticos era habitual, así lo atestiguan los numerosos casos documentados por toda la geografía española del siglo XVI ${ }^{102}$. De hecho, en nuestro caso, la primera referencia a esta financiación conjunta se deja entrever en la misiva que remite el provisor del arzobispado sevillano a los regidores jerezanos en $1549^{103}$. El provisor comunicaba su buena disposición a la solicitud dada por el municipio para que el vicario permitiese que las fábricas de las iglesias de Jerez aportasen una cantidad a la financiación de unos instrumentistas musicales cuya presencia en la ciudad beneficiaba a ambas entidades. Ignoramos la duración de esta primera colaboración entre ambos cabildos para sostener económicamente a los ministriles, pero pudo ir paralela a las ayudas que el ayuntamiento concedía al maestro de capilla de la iglesia mayor colegial.

Lo cierto es que, como ya se indicó, desde 1574 existe constancia de la contratación de un grupo de chirimías por parte de la Colegial ${ }^{104}$, un grupo que pensamos que es el mismo que pocos años después encontramos trabajando permanentemente para el ayuntamiento jerezano, así como para otras parroquias de la ciudad.

La relación de los ministriles municipales con el cabildo eclesiástico será estrecha. La mayoría de estos ministriles se avecindan en la collación de San Salva-

101. AHMJF, sec. I, Actas Capitulares, tomo 28 (años 1581-1584), ff. 755, 1018, 1115, 1150; AHMJF, sec. I, Actas Capitulares, tomo 30 (años 1585-1586), ff. 65, 150, 193.

102. Ruiz Jiménez 2004, pp. 207-208.

103. AHMJF, sec. I, Actas Capitulares, tomo 16 (años 1548-1550), f. 85.

104. Reppeto Betes, p. 27. 
dor, en viviendas destinadas para servidores del cabildo colegial dentro del recinto de la propia iglesia mayor ${ }^{105}$.

Los ministriles se obligaban anualmente con el cabildo colegial y con otras parroquias. Hemos logrado hallar contratos con las San Salvador, Santiago y San Miguel, que pasaban por ser las más ricas del momento. La soldada anual para la copia por acudir a las celebraciones principales de cada iglesia era pagada en especie e iban de los 5 cahices de trigo que daba la iglesia mayor a los 2 cahices que pagaba la parroquia de Santiago o los 3 de San Miguel ${ }^{106}$.

La capilla musical de la Colegial de San Salvador parece que dejará de contar con los servicios de los ministriles a partir del asiento que estos hacen con la institución municipal en 1646. En este contrato se les obligaba a servir a esta ciudad de Xerez de la frontera en todos los efectos de su serbiçio y dependiente de su cabildo y ayuntamiento y no de otro cabildo eclesiástico ni secular ${ }^{107}$.

Tras esta pequeña digresión, volvamos a esos 420 ducados que las facultades reales fijaban desde fines del XVI para el mantenimiento de los servicios de los ministriles ${ }^{108}$. Estos 420 ducados se habían mantenido hasta al menos 1620 para mantener a los cinco ministriles ${ }^{109}$. Sin embargo, en 1629 este sueldo se reducirá a 400 ducados. La causa fue la muerte del ministril tiple Antonio Romero. En 1630, el ministril Miguel de Torres explicaba al cabildo que:

en el asiento que mis antepasados hisieron con la ciudad fue que se le señalasen a sinco ministriles quatrosientos y veinte ducados, a los quatro ministriles ochenta ducados y al tiple veynte ducados mas por ser el trabaxo muncho más que los demás instrumentos.

En efecto, como ya vimos, el reparto de los sueldos no había sido uniforme entre todos los ministriles. Torres proseguía su instancia relatando que llevaba dieciséis años sirviendo a la ciudad supliendo en el puesto de tiple a Antonio Romero tiple por estar ya muy viexo y abrá dos años que totalmente está ynpedido sin poder acudir a servir sus obligaciones. Romero acaba de fallecer y Torres quería que se le asentase la plaza vacante y su sueldo.

105. APNJF, tomo 1053 (oficio 10, año 1605), f. 363. En el patio tenían sus viviendas, en 1605, Gonzalo Sedano y Antonio Romero. Su compañero Juan de Torres también había tenido su casa junto a dicha iglesia, como se demuestra en el arrendamiento de ella que otorga Gonzalo Sedano en nombre de la viuda de Torres: APNJF, tomo 1053 (oficio 10, año 1609), 13 de marzo.

106. AHMJF, tomo 848 (oficio 1, año 1588), 9 de junio; AHMJF, tomo 1293 (oficio 11, año 1620), 1 septiembre; AHMJF, tomo 1053 (oficio 10, año 1605), f. 793.

107. Este asiento lo firmaron Miguel de Torres Hinojosa, Esteban de Torres Hinojosa, Cristóbal Muñoz Bejarano, Domingo de Rebordelo, Antonio de Pereira y Pedro Ortiz de Ribera, ministriles vecinos de la ciudad en la collaciones de san Salvador, de san Lucas y san Dionisio y todos seis compañeros. AHMJF, sec. I, Actas Capitulares, tomo 58 (años 1646-1647), ff. 124v.-125. En las relaciones de ministriles al servicio de la Colegial sólo encontramos el nombre de Esteban de Torres Hinojosa asentado en el año 1666 (Repetto Betes 1980, p. 99).

108. Por esos mismos años, los cuatro ministriles al servicio del cabildo de Sanlúcar de Barrameda, que además de servir al municipio formaban parte de la capilla ducal de la Caridad, recibían 100 ducados cada uno más 6 cahices de trigo, casa y servicios médicos: Daza Palacios 2009, p. 155.

109. AHMJF, sec. I, Actas Capitulares, tomo 46 (años 1624-1625), f. 1012v. 
Sin embargo, el fallecimiento de Romero fue para el ayuntamiento una irrenunciable oportunidad para hacer un recorte en el capítulo de gastos de personal. Así lo deja bien patente la implícita negativa de los capitulares a la petición de Miguel de Torres para que el contador municipal diera testimonio de los libros de cuentas y gastos del ayuntamiento del salario que se había acostumbrado a pagar a los ministriles tiples mis antecesores de quarenta años a esta parte. Los capitulares acordarán, sin contemplaciones, que no había lugar a la petición de Torres, añadiendo que todos los ministriles debían acudir sin falta alguna a sus obligaciones, pagándoseles a todos por igual ochenta ducados ${ }^{110}$. Y si esto fuera poco, remataban el acuerdo "animando" a los ministriles a enseñar a otros y exercitarse que la ciudad entonces tendrá consideración a gratificarles y pagallos ${ }^{111}$.

Esta última declaración que resaltamos venía por la petición que había hecho Cristóbal de Palacios meses antes. Relataba que cuando se le nombró ministril en 1623 se le había asentado entre sus obligaciones el que tuviese escuela para enseñar a los hijos de vecinos que desearan aprender el oficio. Palacios contaba que se le había señalado el mismo salario de 30.000 maravedíes de los demás ministriles, pese a estas obligaciones extras. Por tanto, suplicaba un aumento de salario por ser como soy pobre y no tengo otros bienes sino es mi oficio. Fue en balde ${ }^{112}$. Esta obligación que tendría como objetivo combatir la endogamia del oficio que se estaba reproduciendo en la copia municipal había sido propuesta por algunos regidores en el ya referido cabildo de 1585 y se incluirá en los posteriores asientos.

Se puede comparar la asignación que a mediados del siglo XVII se destinaba al pago de los ministriles - los citados 400 ducados- con otros sueldos municipales. El corregidor seguía recibiendo el sueldo más alto con 700 ducados, Los Veinticuatros, 8 ducados cada uno; el mayordomo de Propios recibía 1.650 reales; los abogados municipales recibían 20 ducados. En total, el ayuntamiento jerezano gastaba anualmente en sueldos y otros gastos ordinarios un total de 153.885 reales ${ }^{113}$. De ahí, los 400 ducados suponían el 2,8 \% de los gastos municipales.

Pese a todo, este salario no daba una alta seguridad económica. Las manifestaciones van en la línea de la pobreza de sueldo. Algo que pudo derivar en situaciones de absentismo de sus obligaciones por parte de los músicos para atender a otros demandantes de sus servicios, pero quizás también como forma de protes$\operatorname{ta}^{114}$. En 1585, con las arcas municipales ahogadas, los regidores debatían cómo solucionar las continuas peticiones de los ministriles para que el mayordomo de los Propios les pagase su salario. Algunos veinticuatros proponían ante la falta de

110. Ochenta ducados fue el sueldo que se le fija a Antonio Pereira y a Domingo Pereira en ese mismo año: AHMJF, sec. I, Actas Capitulares, tomo 48 (años 1629-1631), ff. 760-761, 893-894.

111. AHMJF, sec. I, Actas Capitulares, tomo 48 (años 1629-1631), ff. 737 r.-v., 760-761.

112. AHMJF, sec. I, Actas Capitulares, tomo 48 (años 1629-1631), ff. 748 -748v.

113. AHMJF, sec. I, Actas Capitulares, tomo 63 (años 1655-1656), ff. 231-239.

114. Estas ausencias dieron muncha nota en la ciudad en 1597: AHMJF, sec. I, Actas Capitulares, tomo 36 (años 1597-1598), f. 241. Casos de esta conflictividad laboral: Bejarano Pellicer 2013, pp. 93-107. 
dinero tomar prestado de las imposiciones lo que se les debía atento a que son gente pobre e no tienen otra cosa de que alimentarse sino lo que cibdad les $\mathrm{da}^{115}$.

No obstante, algunos ministriles disfrutan de una cierta solvencia económica, cuyo origen bien pudiera estar en el trabajo paralelo para otras personas o instituciones demandantes de los servicios musicales ${ }^{116}$, o quizás por dotes matrimoniales ${ }^{117}$. Esta solvencia económica se manifiesta en los casos de Andrés y Gonzalo Sedano o en el de Juan de Torres, quienes la invertirán en pequeñas propiedades de tierra y de viña ${ }^{118}$.

Ya referimos que en 1654 Esteban de Torres Hinojosa señalaba la devaluación del salario como origen de las continuas deserciones en la copia de ministriles que se estaban sucediendo en aquellos años ${ }^{119}$. Esta situación, según señalaba Torres, fue fruto del asiento que se hizo en 1645 por el que se aumentó a seis el número de ministriles. Aunque este aumento fue promovido por los propios ministriles, los cuales de "conformidad" aceptaron repartir entre los seis los 400 ducados que había cobrando la copia de cinco ministriles (bino Pedro Ortis y porque hera buen oficial de sus instrumentos pedimos a vuesa señoria que lo admitiera en su servicio relataba Torres). Pese a que el citado asiento y repartimiento de 1645 aun estaba vigente -pues se firmó por un periodo de diez años- Esteban de Torres requería al cabildo que se volviese a los sueldos anteriores, pues contaba que

poniendo muncha diligencia e traído los compañeros que oy tengo que son cuatro yo cinco y el traerlos fue disiéndoles se abia de darles de salario ochenta ducados para cada uno conforme al primer asiento de cuatrosientos ducados entre cinco.

El ayuntamiento dejó en manos de los diputados de Fiestas la resolución del caso. No se sabe nada más.

Esta reducción de sueldo, junto con la prohibición de compaginar sus empleos con otros demandantes de servicios musicales estipulada en los nuevos asientos, pudo ser la causa de que en pocos años el municipio pierda el servicio de los ministriles.

115. AHMJF, sec. I, Actas Capitulares, tomo 30 (años 1585-1586), f. 514.

116. En 1576 la hermandad sacramental de San Mateo de Jerez pagaba 84 reales a los ministriles que asistieron desde las primeras vísperas hasta las segundas desta fiesta (Corpus Christi) y algunas noches. También se pagó 50 reales a los cantores. Archivo Hermandad del Desconsuelo de Jerez de la Frontera. Fondo Hermandad Sacramental. Libro de Cuentas (1576).

117. Francisco de Villena recibió de su mujer Isabel Muñoz 300 ducados en muebles y en 7 aranzadas de viña: APNJF, Tomo 840, oficio 13, año 1587, ff. 102 r-v. 300 ducados recibe en 1614 Diego Sedano: APNJF, oficio 12, año 1614, f. 1.249. Son dotes de mediana entidad. Al respecto de las dotes de ministriles: Bejarano Pellicer 2013, pp. 72-78.

118. AHMJF, tomo 1146 (oficio 10, año 1611), 24 octubre; tomo 1293 (oficio 11, año 1620), 1 septiembre, f. 1583; tomo 1053 (oficio 10, año 1605), f. 793. El trompeta Diego Martin por su parte arrendaba sus dos aranzadas de viña por 20 ducados: APNJF, tomo 455 (oficio 15, año 1563), f. 1348

119. AHMJF, sec. I, Actas Capitulares, tomo 62 (años 1654), f. 350v. 


\section{CONTEXTOS Y FUNCIONES DE REPRESENTATIVIDAD DE LOS MÚSICOS MUNICIPALES}

Para conocer cuál fue la actividad patrocinada por el poder civil jerezano en la que se articularon las obligaciones que los músicos contraían con la institución municipal es preciso volver a los asientos de estos servicios musicales. De este modo, las obligaciones que firma en 1562 el ministril Diego Rodríguez en nombre de su compañía fueron:

de serbir a esta yllustre cibdad las fyestas syguyentes = la fiesta del corpus xpi, la fiesta del señor san juan, la fiesta del señor santiago, san dionys, la fiesta del señor san sebastian y todas las bezes questa çibdad saliere a los rrebatos de moros y todas las otras fyestas estraurdynarias questa la çibdad toviere ansy de juegos de cañas e toros e rregozijos que obiere por fyestas de su magestad e por otras en qualquier manera y la fiesta del señor san dyonis y todas las de los que por parte desta ilustre çibdad fuere llamado ${ }^{120}$.

Este documento diferencia dos tipos de contextos ceremoniales o celebrativos: el ordinario y el extraordinario. El ordinario incluye en primer lugar una serie de "fiestas" de carácter religioso. Dentro de estos servicios ordinarios, los músicos, en este caso los trompetas, tendrán que acompañar a la milicia de la ciudad en sus distintas salidas. Fuera de lo ordinario estarían todos aquellos festejos o eventos de carácter áulico y, en definitiva, todo aquel acto en que el ayuntamiento requiriese de los servicios de los músicos.

La función militar fue, no obstante, la principal argumentación dada ante el rey para solicitar las licencias para pagar a los ministriles. En la concedida en 1592 se expresaba que la cercanía de Jerez a los puertos marítimos le obligaba a prestar continua ayuda en las ocasiones de enemigos que de ordinario se ofresian, y que por espirensia se avia visto que con los ministriles se anymava la cavalleria y la demás gente nessesaria para que con presteza se acudiese a los rebatos. Esta obligación no estará exenta de peligro para los músicos, como sucedió en 1596, cuando fueron hechos cautivos, junto a gran parte de la milicia jerezana, en el saqueo inglés de la ciudad de Cádiz, donde fueron presos despojados de nuestros vestidos $y$ armas y dineros. Pero la perdida mayor fue la de haberles sido arrebatados los ynstrumentos de nuestro ofisio y por ser de mucho valor y nosotros quedamos ynposibilitados de poderlos hazer de nuevo. Los capitulares acordaron librar de la partida destinada a gastos de guerra cuarenta ducados de ayuda para comprar los instrumentos de su oficio pues paresce los perdieron en la jornada de Cádiz en servicio desta ciudad ${ }^{121}$.

A diferencia del asiento de 1562, así como de las citadas argumentaciones que se hacía en las facultades reales, en el asiento de 1646, que reproducía literalmente uno anterior de 1644, ya no se hace referencia explícita a las actuaciones de los

120. AHMJF, sec. I, Actas Capitulares, tomo 20 (años 1562-1564), f. 286 v.

121. AHMJF, sec. I, Actas Capitulares, tomo 35 (años 1595-1596), f. 869. 
músicos dentro de los ejercicios y maniobras en las que participaban las compañías militares de la ciudad. Este contrato es interesante pues muestra el aumento de la actividad ceremonial del cabildo jerezano, así como el papel principal que los ministriles ocupan en ella:

asistir en la plaça del arenal a la carrera así en días de fiesta como de trabajo y en qualquier reguçixo y fiestas de toros questa ciudad hiçiere en la plaça del arenal della y en otras partes y en todas las torres de noche ${ }^{122}$ a las fiestas y rregoçixos que hiçiere y tiene dotadas y quando la ciudad salga del ayuntamiento e buelba a él y oficiar las missas de todas las fiestas en las yglesias donde la ciudad las hiçiere y rreçivir a la ciudad quando bolbiere a su ayuntamiento de dicha fiesta procesiones y exequias funerales y al levantamiento del pendón real y a la debulgaçion de la santa bulla y publicación de çedulas y cartas y prematicas reales de su magestad de forma que an de asistir a todas las partes fiestas y actos públicos donde la ciudad asistiere y en las que hiçieren por su orden con toda puntualidad y cuidado tocando sus instrumentos con toda perfeccion ${ }^{123}$.

Es decir, un amplísimo conjunto de situaciones en las que la música se integraba con las demás artes y artificios en un barroco bel composto que ensamblaba ese todo que era la fiesta pública.

\section{LOS TROMPETAS Y MINISTRILES MUNICIPALES DE JEREZ. APROXIMACIÓN SOCIOLÓGICA}

El fuerte carácter endogámico es quizá el aspecto social más reseñable de los músicos durante los siglos XVI Y XVII. Así, las sagas de los Sedano y los Torres acapararán la copia de ministriles municipales cerca de ochenta años ${ }^{124}$. Una endogamia, que también estuvo presente en los trompetas municipales que les antecedieron. Andrés Sedano, Diego Sedano y Juan de Torres se asientan en la copia municipal, y pronto introducen en ella a sus hijos y nietos. Esto dificultará la entrada de otros músicos, ya fueran nacidos o no en Jerez. Asimismo, esto dará poca cabida a que otros jerezanos se formen en esta profesión. La obligación que tendrán los ministriles de enseñar el oficio a los hijos de los vecinos parece que dará escasos resultados; así las vacantes que se producen en la copia y que no son ocupadas por los familiares de los Sedano o los Torres son cubiertas con ministriles foráneos. Y nuevamente, el aspecto familiar es el que predomina: son los casos de Antonio y Domingo Pereira y de Juan de Aguilar y Francisco de Aguilar.

122. Era usual que tocaran desde lugares altos como torres o balcones. Quizás se deba relacionar con esta particularidad la condición que el trompeta municipal Francisco Salcedo puso al traspasar en 1561 el arrendamiento de 17 ducados anuales de una casa en la plaza del Arenal. La condición era poder hacer libre uso de una bentana grande de las dos que están en el soberado de las dichas casas que salen a el arenal [...] los dias de fiesta y toros: APNJF, tomo 438 (oficio 15, año 1563), f. 479.

123. AHMJF, sec. I, Actas Capitulares, tomo 58 (años 1646-1647), fe. 124-125v.

124. Véase otros casos similares en: Bejarano Pellicer 2013, pp. 37-43, 232. 
Este fuerte carácter endogámico se fortalece con las redes sociales en la que se integran. Tal fue el caso del ministril Antonio Romero que casará una hija con el maestro mayor de la capilla musical de la iglesia Colegial, Bartolomé Méndez ${ }^{125}$. Las relaciones de Romero con otros maestros de capillas y canónigos de la iglesia mayor Colegial, lógicas por otro lado, se fijan en el papel con la presencia de éstos en los bautizos de sus hijos ${ }^{126}$.

La vinculación de los ministriles con las instituciones para las que trabajaban debió, asimismo, de ofrecer a estos profesionales otros tipos de provechos más allá de una cierta seguridad en el ámbito económico. Estos serían réditos que se adentran en el terreno del prestigio social. Es significativo que en todos los memoriales que estos músicos remitan al aristocrático cabildo jerezano se titulen como criados de vuestra señoría. Los ministriles se relacionan con las élites de la sociedad jerezana ${ }^{127}$, alentándose en ellos un sentimiento de superación y auto-estimación social. Asimismo, las relaciones con instituciones religiosas también posibilitarían vías de integración social y de promoción laboral, tal el caso de Francisco de Villena con el convento de Santo Domingo y sus hermandades del Rosario y del Nombre de Jesús.

Una estrategia social de cariz nobiliario fue la de destinar a algunos de los hijos al estamento eclesiástico. Por ejemplo, Esteban de Torres Hinojosa. Al igual que hizo su padre con su hermano, el presbítero Baltasar de Torres, enviará a su hijo Francisco a iniciar una fructífera carrera dentro de la orden dominica ${ }^{128}$.

Para finalizar esta rápida visión, hay que señalar la soltura con que firman los ministriles jerezanos en los documentos notariales que hemos analizado (figura 1). Este es un dato que incide en la buena alfabetización que, por norma general, tuvieron estos profesionales de la música ${ }^{129}$. Una formación intelectual que, unida a las relaciones sociales apuntadas, hará posible, por ejemplo, que Diego Sedano además de continuar tañendo como ministril ejerza el oficio de mayordomo de la fábrica de la iglesia mayor de Jerez ${ }^{130}$.

125. En enero de 1630 el maestro de capilla pedía al cabildo los nueve meses de salario que se le debía a su difunto suegro. El ayuntamiento lo concederá: AHMJF, sec. I, Actas Capitulares, tomo 48 (años 1629-1631), f. 833. Hay que señalar la hipótesis de su posible relación familiar con el violero Baltasar Méndez, quien en 1615 pide licencia de seis meses al cabildo jerezano para usar su oficio y tener tienda publica en el interin se examina: AHMJF, sec. I, Actas Capitulares, tomo 43 (años 16151617), f. 83.

126. AHDAJ, Parroquial, San Salvador, bautismos (1598-1608), ff. 49v., 90v., 137. Cabe la posibilidad de que Leonor de Medina, mujer de Juan de Torres, pudiera pertenecer a la importante familia de ministriles sevillanos Medina: Bejarano Pellicer 2013, pp. 278-279.

127. Como el caso del trompeta Juan Rodríguez quien junto a otras personalidades es testigo de la escritura de dote de la hija del comendador Hernando de Padilla: APNJF, tomo 200 (oficio 3, año 1540), f. 365.

128. Góngora 1890, LXIV.

129. Gonzalo Sedano rubrica con una especie de clave de sol. Esta curiosa rúbrica de la que existen otros ejemplos en Sevilla permite aventurar su alfabetización musical (Bejarano Pellicer 2012, pp. 39-63; Bejarano Pellicer 2014, p. 48), pero también su auto-afirmación como músico. Los trompetas localizados, en cambio, declaran no saber firmar: Francisco Salcedo: APNJF, tomo 438 (oficio 15, año 1562), f. 479; Diego Martín: APNJF, tomo 455 (oficio 15, año 1563), f. 1348.

130. AHMJF, sec. I, Actas Capitulares, tomo 16 (años 1624-1625), f. 1151v. 


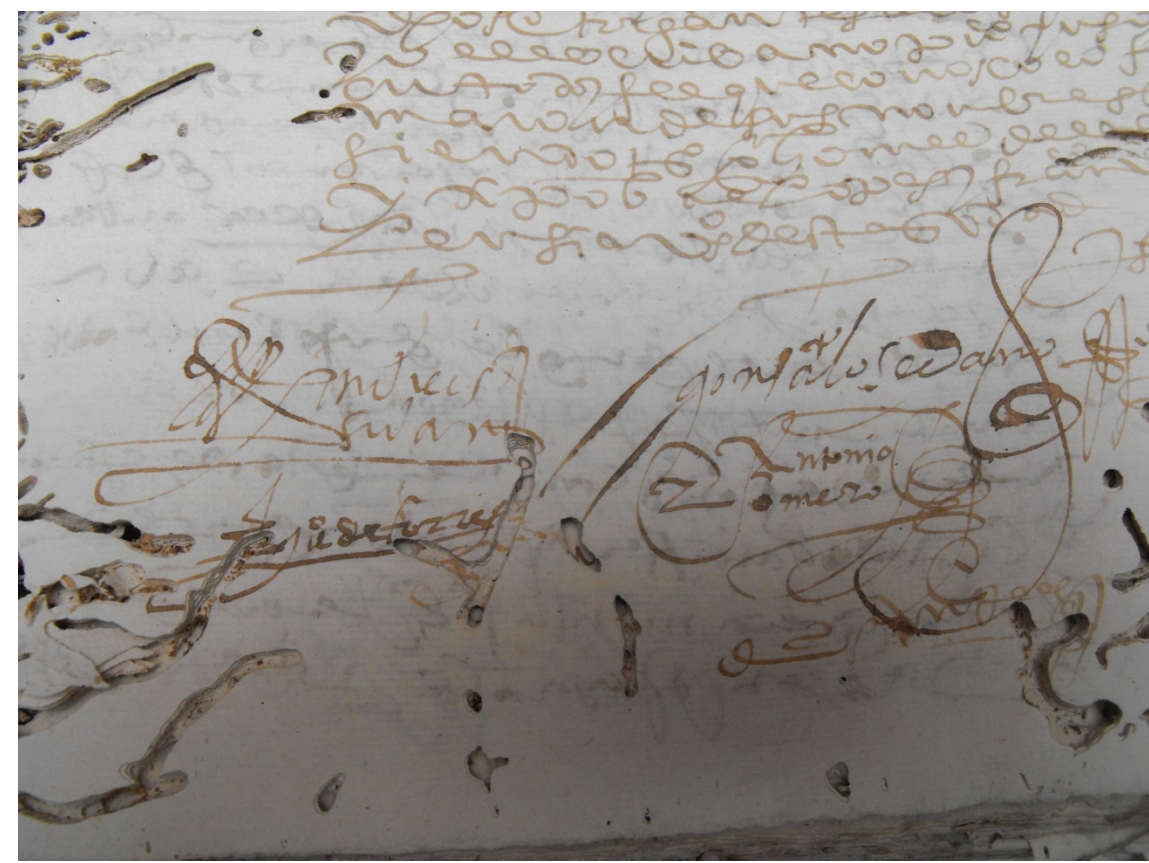

Fig. 1. Firmas de los ministriles Andrés Sedano, Gonzalo Sedano, Juan de Torres y Antonio Romero. APNJF, tomo 1053 (oficio 10, año 1605), f. 793.

\section{BIBLIOGRAFÍA}

Andrés, Ramón (2009), Diccionario de instrumentos musicales, Barcelona.

Astruells Moreno, Salva (2005), "Los ministriles altos en la corte de los Austrias mayores", Brocar, 29, La Rioja, pp. 27-52.

Atkinson, Niall (2016), The Noisy Renaissance: Sound, Architecture, and Florentine Urban life, University Park (PA), Pennsylvania State University Press.

Bejarano Pellicer, Clara (2012), "Sobre la alfabetización de los ministriles sevillanos: Los músicos sevillanos a través de sus firmas (1570-1650)", Historia. Instituciones. Documentos, 39, pp. 39-63.

Bejarano Pellicer, Clara (2013), El mercado de la música en la Sevilla del Siglo de Oro, Sevilla.

Carreras López, Juan José (2005), "Música y ciudad: de la historia local a la historia cultural”, en Marín López, Miguel Ángel; Bombi, Andrea; Carreras López, Juan José (coords.), Música y cultura urbana en la Edad Moderna, Valencia, pp. 17-52.

Carter, Tim (2005),’El sonido del silencio: modelos para una musicología urbana”, en Marín López, Miguel Ángel; Bombi, Andrea; Carreras López, Juan 
José (coords.) Música y cultura urbana en la Edad Moderna, Valencia, pp. 53-68.

Daza Palacios, Salvador (2009), Música y sociedad en Sanlúcar de Barrameda (1600-1975), Sevilla.

García Guzmán, María del Mar- Pérez Abellán, Juan (1997), La religiosidad de los jerezanos según sus testamentos: (siglo XV), Cádiz.

Gómez Fernández, Lucía (2017), Música, nobleza y mecenazgo. Los duques de Medina Sidonia en Sevilla y Sanlúcar de Barrameda (1445-1615), Cádiz.

Góngora, Diego Ignacio de (1890), Historia del Colegio Mayor de Santo Tomás de Sevilla, Sevilla.

Martín Gutiérrez, Emilio (1996), “Aproximación a la hacienda jerezana en el siglo $\mathrm{XV}$ : las cuentas de propios del año 1482", Estudios de historia y de arqueología medievales, 11, pp. 179-189.

Murrell Stevenson, Robert (1974), Christmas music from baroque Mexico, Londres.

Repetto Betes, José Luis (1980), La capilla de música de la Colegial de Jerez: (1550-1825), Jerez de la Frontera.

Robledo Estaire, Luis (2000), "La transformación de la actividad musical en la corte de Felipe III", Robledo Estaire, Luis et all.(2000), Aspectos de la cultura musical en la Corte de Felipe II, Madrid, Alpuerto, 2000, pp. 173-186.

Ruiz Jiménez, Juan (2000), "Ministril”, Casares Rodicio, Emilio, Diccionario de la Música Española e Hispanoamericana, vol. 7, Madrid, pp. 593-597.

Ruiz Jiménez, Juan (2004), "Ministriles y extravagantes en la celebración religiosa", en Suárez Pajares, Javier; Griffiths, John (coords.) (2004), Políticas y prácticas musicales en el mundo de Felipe II: estudios sobre la música en España, sus instituciones y sus territorios en la segunda mitad del siglo XVI, Madrid, pp. 199-240.

Sanz Ayán, Carmen (2009), "Fiesta y poder (siglos XVI y XVII)" Studia historica. Historia moderna, 31, pp. 13-17.

Strong, Roy (1988), Arte y poder: fiestas del Renacimiento, 1450-1650. Madrid. 